\title{
Micro- and Nanotechnology for HIV/AIDS Diagnostics in Resource-Limited Settings
}

\author{
Gregory L. Damhorst, Nicholas N. Watkins, and Rashid Bashir*, Fellow, IEEE
}

\begin{abstract}
Thirty-four million people are living with HIV worldwide, a disproportionate number of whom live in resource-limited settings. Proper clinical management of AIDS, the disease caused by HIV, requires regular monitoring of both the status of the host's immune system and levels of the virus in their blood. Therefore, more accessible technologies capable of performing a CD4 $+\mathrm{T}$ cell count and HIV viral load measurement in settings where HIV is most prevalent are desperately needed to enable better treatment strategies and ultimately quell the spread of the virus within populations. This review discusses micro- and nanotechnology solutions to performing these key clinical measurements in resource-limited settings.
\end{abstract}

Index Terms-Global health, human immunodeficiency virus (HIV)/acquired immune deficiency syndrome (AIDS), micro- and nanotechnology, point-of-care $(\mathrm{PoC})$ diagnostics.

\section{INTRODUCTION}

A PPROXIMATELY 34 million people worldwide are living with human immunodeficiency virus (HIV), the virus that causes acquired immune deficiency syndrome (AIDS) [1]. Epidemiological trends reflect recent progress in the expansion of access to prevention, testing, counseling, and treatment, including a drop in new HIV infections from 3.1 million annually in 2002 to 2.7 million in 2010 and a decline in AIDS-related deaths from 2.2 million annually in 2006 to 1.8 million in 2010 [1].

These data do not mask the epidemic proportions of the disease, however, and combating HIV/AIDS remains one of eight Millennium Development Goals outlined by the United Nations for reducing extreme poverty [2]. The disease disproportionately affects the world's poorest nations-for example, $68 \%$ of all people living with HIV reside in Sub-Saharan Africa, a region that represents only $12 \%$ of the global population [1]. Because of the absence of an effective vaccine, the availability of

Manuscript received December 26, 2012; revised January 25, 2013; accepted January 26, 2013. Date of current version March 7, 2013. Asterisk indicates corresponding author.

G. L. Damhorst is with the Department of Bioengineering and the Micro and Nanotechnology Laboratory, University of Illinois at Urbana-Champaign, Urbana, IL 61801 USA (e-mail: gdamhor2@illinois.edu).

N. N. Watkins was with the Department of Electrical and Computer Engineering and the Micro and Nanotechnology Laboratory, University of Illinois at Urbana-Champaign, Urbana, IL 61801 USA. He is now with Nabsys, Inc., Providence, RI 02903 USA (e-mail: watkins7@illinois.edu).

${ }^{*} \mathrm{R}$. Bashir is with the Department of Electrical and Computer Engineering, the Department of Bioengineering, and the Micro and Nanotechnology Laboratory, University of Illinois at Urbana-Champaign, Urbana, IL 61801 USA (e-mail: rbashir@illinois.edu).

Color versions of one or more of the figures in this paper are available online at http://ieeexplore.ieee.org.

Digital Object Identifier 10.1109/TBME.2013.2244894

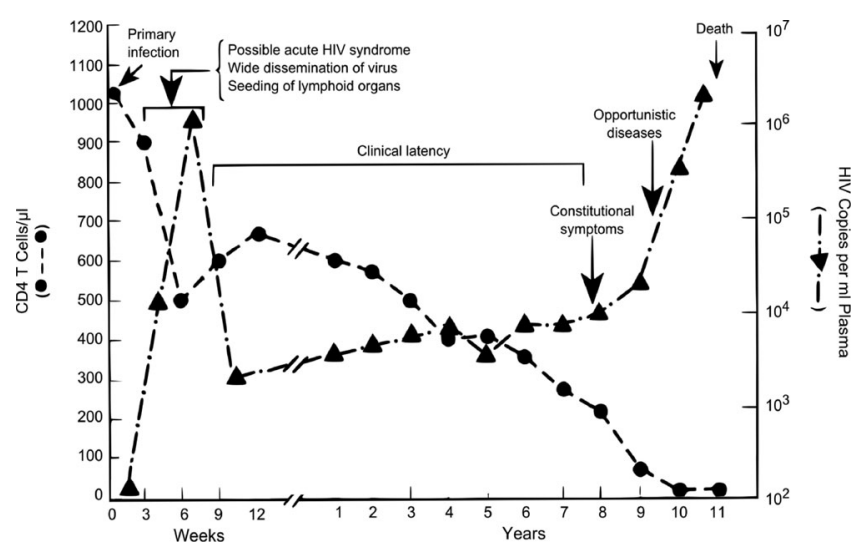

Fig. 1. Typical course of infection. Typical CD4 counts and plasma viral load during the course of an HIV infection. Adapted from [4] and [5].

antiretroviral medications and accessibility of testing represent the most significant grand challenges in fighting the HIV/AIDS epidemic worldwide. These two challenges do not stand independently, however, as regular and appropriate monitoring is required for effective treatment.

HIV infection is typically diagnosed by serologic tests indicating the presence of anti-HIV antibodies, a test for which rapid point-of-care (PoC) assays are available including tests of oral fluids and whole blood from a finger prick [3]. Following diagnosis, guidelines issued by the Infectious Disease Society of America recommend immediate evaluation of two core markers of the progress of infection: the CD4+ T lymphocyte count and plasma viral load, in addition to antiretroviral therapy (ART) resistance testing, a complete blood count, and blood chemistry panels [3]. Typical levels of CD4+ T lymphocytes and plasma viral load during the course of HIV infection are depicted in Fig. 1 [4], [5]. World Health Organization (WHO) guidelines recommend the initiation of ART for people living with HIV upon determination of a CD4 count less than or equal to 350 cells $/ \mathrm{mm}^{3}$, while CD4 count monitoring is recommended to be performed at least every six months for individuals not yet eligible for ART [6]. During treatment, the WHO recommends CD4 counting and viral load monitoring in a routine approach [6]. Ultimately, the goal of regular monitoring is to guide treatment strategies toward the prevention of immunological failure (CD4 count below baseline, $50 \%$ of ontreatment peak value, or 100 cells $/ \mathrm{mm}^{3}$ ), and virological failure (viral load above 5000 copies $/ \mathrm{mL}$ ) [6].

The CD4 count reflects the health of the immune system and is occasionally paired with the CD8 $+\mathrm{T}$ lymphocyte count in assessment of an HIV+ patient, although there are conflicting reports on the utility of CD8 counts or CD4/CD8 ratio [3], [7]. 


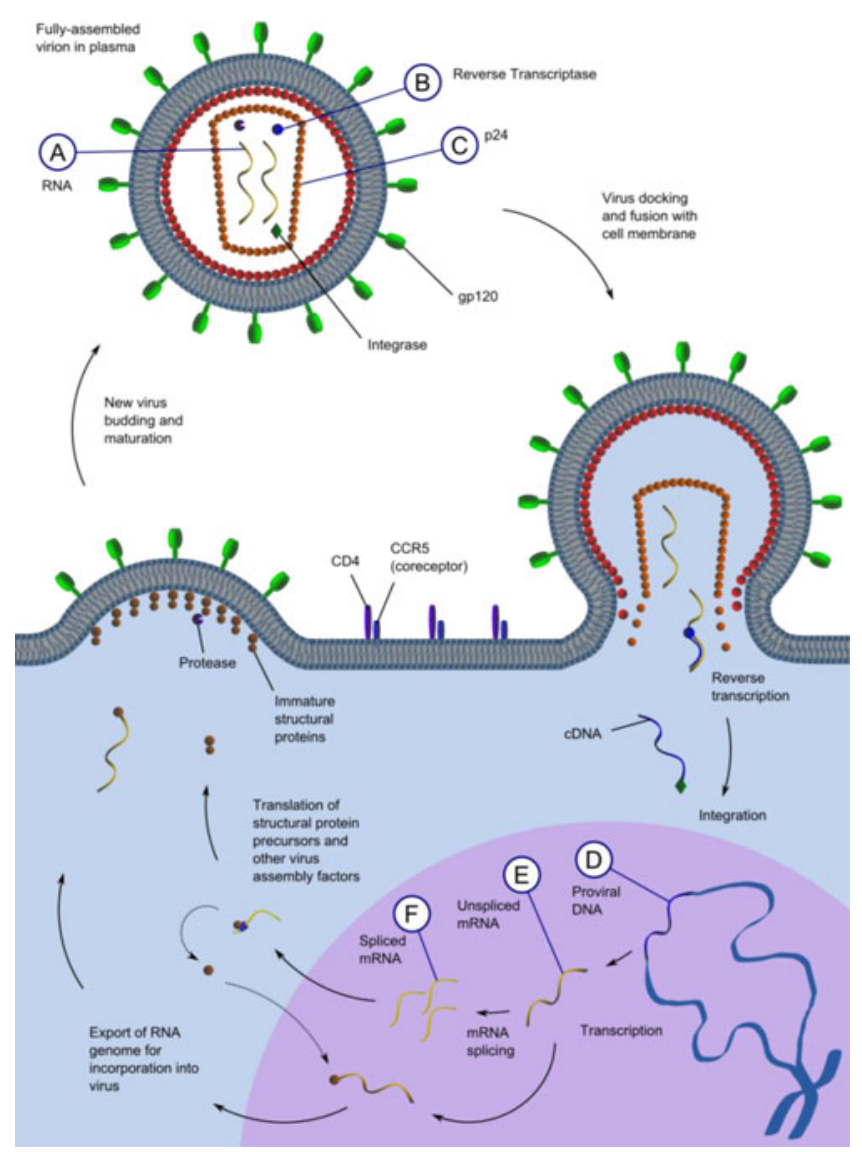

Fig. 2. HIV lifecycle showing critical points for virus detection. Virions in plasma infect CD4+ T lymphocytes via the high-affinity interaction between the viral surface protein gp 120 and the host cell CD4 receptor and CCR5 coreceptor. This docking facilitates fusion of the viral and cell membranes and injection the protein capsid into the cytoplasm which dissociates to release viral RNA. Highly error-prone RT makes a cDNA copy of the viral genome which is targeted to the host cell nucleus and integrated with the host genome by viral protein integrase. Host cell gene expression including mRNA alternative splicing ensues, resulting in expression of both viral structural protein precursors and those involved in the facilitation of viral gene expression. Genomic RNA and structural proteins are targeted to the cell surface where budding occurs. Maturation facilitated by protease action takes place after budding. Labels indicate biomarkers for viral diagnostics, including (A) viral RNA in plasma, (B) RT in plasma, (C) capsid protein p24 in plasma, (D) proviral DNA, (E) cell-associated unspliced RNA, and (F) cell-associated spliced RNA.

Viral load measurements complement the CD4 count and are a direct assessment of viral number. Viral load is typically assessed by quantifying viral RNA in the blood plasma, although alternative approaches to quantifying plasma load as well as intracellular viral reservoirs have been described. A review of the HIV lifecycle in Fig. 2 reveals several traditional and alternative biomarkers for monitoring virus levels.

Because of retrovirus integration with the host in the form of a provirus, HIV establishes a long-term reservoir and accomplishes production of new virions in host cells-a process that can be interrogated at all levels of gene expression inside the cell. Detection of proviral DNA is the most commonly assessed intracellular marker and has established clinical relevance as a method for assessing virus status in newborns in whom motherto-child transmission of HIV is suspected, since passive transfer of maternal antibodies can produce false positives on serolog- ical tests [3]. However, assessment of levels of cell-associated unspliced and multiply spliced HIV RNA has also been suggested as clinical markers of disease progression [8]-[10], to have prognostic value [11], or to be useful metrics for assessing ART efficacy [12], [13]. Laboratory-based methods for the detection of cell-associated RNA have been demonstrated [14], [15].

The core principles of micro- and nanotechnology offer opportunities for new approaches to monitoring all of these biomarkers. Modern fabrication techniques have enabled the development of novel optical, mechanical, and electrical biosensor platforms with greater sensitivity for cell and biomolecule sensing, including those which replace or eliminate the need for expensive and bulky components of state-of-the-art clinical diagnostic instruments. Microfluidic systems enable precise manipulation of small volumes of biological fluids, significantly decreasing blood sample size requirements and allowing for less invasive collection techniques. Finally, smaller instrument footprints promise a high degree of portability in sample-to-answer systems.

This paper emphasizes approaches toward the implementation of technologies for CD4 T lymphocyte counting, plasma viral load, and proviral load determination in resource-limited settings. Approaches vary from adaptations of state-of-the art technologies to novel assays based on innovations in microand nanotechnologies. Several technologies discussed here address testing challenges through complete sample-to-answer integrated systems while others demonstrate partial solutions, yet demonstrate potential for application in an integrated system.

In addition to the typical requirements for sensitivity and specificity required of diagnostic technologies, the criteria for effective CD4 counting or viral load determination in resourcelimited settings include 1) the test must be able to operate at the PoC, addressing the need to bring testing to patients with limited ability to travel to a healthcare facility, 2) the test must be rapid, addressing complications in resource-limited settings associated with healthcare provider follow-up when results cannot be obtained same day, 3) the test must be low-cost, mitigating the financial burden on individuals, agencies, or governments in poor countries, and 4) the test must be easy to use, allowing for implementation in areas where skilled technicians are not available. The end goal is a comprehensive technology capable of taking whole blood input in the form of a finger-prick or heel-prick, and outputting the desired results.

\section{Plasma ViRAL LOAD}

\section{A. Current State of the Art}

Several challenges complicate the monitoring of HIV plasma viral load, including the diversity of HIV forms and subtypes as the result of high recombination and mutation rates-one of the primary barriers to the development of an effective vaccine [16]. Effective viral load devices must therefore be capable of flexibility among genetic or antigenic variation from infection to infection.

State-of-the-art technology for plasma viral load involves amplification and detection of viral nucleic acid. Tests approved by 
TABLE I

FDA-APPROVED TESTS FOR PLASMA VIRAL LOAD QUANTIFICATION

\begin{tabular}{llll}
\hline \hline Test name [17-19] & Manufacturer & FDA Approval [18], [20] & Type \\
\hline Roche Amplicor HIV-1 Monitor Test & Rochem Molecular Systems, Inc. & $3 / 2 / 1999$ & RT-PCR \\
NucliSens HIV-1 QT & bioMerieux, Inc. & $11 / 19 / 2001$ & NASBA \\
VERSANT HIV-1 RNA 3.0 Assay (bDNA) & Bayer Corporation, Berkeley, CA & $9 / 11 / 2002$ & bDNA \\
Abbott RealTime HIV-1 Amplification Kit & Abbott Molecular, Inc. & $5 / 11 / 2007$ & RT-PCR \\
COBAS TaqMan HIV-1 Test & Roche Molecular Systems, Inc. & $5 / 11 / 2007$ & RT-PCR \\
\hline \hline
\end{tabular}

the U.S. Food and Drug Administration for quantification of plasma viral load by nucleic acid amplification are listed in Table I [17]-[20]. To date, however, no reverse-transcription polymerase chain reaction (RT-PCR), branched DNA (bDNA), or nucleic acid sequence-based amplification (NASBA) assay has demonstrated the qualities necessary to become ubiquitous in resource-limited settings.

Multiple studies have also explored the possibility of transporting dried blood or plasma specimens from more primitive sites to a capable laboratory as a global health solution for plasma viral load testing, though this does not address the ultimate need for a rapid, PoC test [21]-[24]. Progress toward viral load in resource-limited settings has emerged in the form of assays for other biomolecular components of HIV, including the structural capsid protein p24 and the enzyme reverse transcriptase (RT), platforms aimed at the miniaturization of the amplification and/or detection aspects of nucleic acid quantification, and isolation of whole viruses from blood samples as a processing step toward direct particle counting. Several novel nonquantitative technologies for detection of HIV in plasma have been reported, including a recent report from De la Rica and Stevens on a gold-nanoparticle-based p24 assay that can be analyzed with the naked eye [25]. Nonquantitative techniques are only presented extensively in this section, however, when considered relevant to the development of a future quantitative technique.

\section{B. Global Health Solutions}

1) Detection of p24 Capsid Proteins: The enzyme-linked immunosorbent assay (ELISA) is a standard technique for laboratory detection and quantification of proteins. P24 assays developed by Perkin Elmer Life Sciences (Boston, MA) [26]-[29], NEN Life Science Products (Geneva, Switzerland) [30], and Biocentric (Bandol, France) [31] have been evaluated for use in resource-limited settings but sensitivity [27], reliability [27], [30], and false positives [31] have been cited as reasons limiting implementation of these tests in resource-limited settings. Alternative assays have been developed, however, for the detection of p24 as the basis for HIV quantification [32]-[36].

Lee et al. sought to improve upon the standard ELISA with a nanoarray patterned with anti-p24 antibodies by dip-pen nanolithography [32]. Instead of an enzyme with chemiluminescent product, a gold nanoparticle probe functionalized with anti-p24 antibody was used as a secondary tag and detected with atomic force microscopy and scanning electron microscopy. While this report serves as an interesting proof of concept, a more ap-

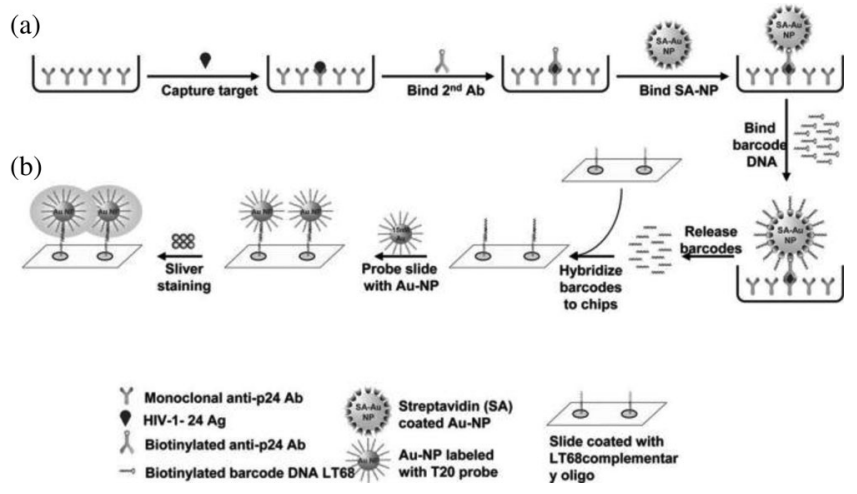

Fig. 3. Biobarcode assay for the detection of HIV p24 antigen. Reprinted from [34] with permission from Lippincott Williams \& Wilkins, Inc.

propriate detection technique is necessary as these microscopy techniques are probably not suited for low-cost, portable applications.

Parpia et al. described a dipstick assay for p24 designed for rapid detection of HIV in infants [33]. Plasma samples were mixed with heat shock buffer, heated to disrupt immune complexes, and then exposed to the dipstick test. The sample hydrates an antibody-conjugated tag and flows laterally by capillarity to a test line where antigen-bound tags are immobilized. The dipstick is then scanned and analyzed by a computer for semiquantitative results. This technique makes strides toward the ideal platform for $\mathrm{PoC}$ viral load determination, although integrated scanning and analysis may be necessary to achieve the desired ease of use.

The concept of a biobarcode detection assay was introduced by Nam et al. [37]. The technique was later adapted for detection of HIV capsid protein p24 [34]-[36] and an overview of the concept is depicted in Fig. 3 [34]. The biobarcode assay is a modification of traditional ELISA techniques in which p24 is first captured in microtiter wells coated with anti-p24 antibody and subsequently tagged with a biotinylated anti-p24 [34]. Streptavidin-coated gold nanoparticles are then bound to the secondary antibody, providing a substrate for attachment of biotinylated barcode DNA. Following washing and heating, biobarcode DNA immobilized on gold nanoparticles bound to $\mathrm{p} 24$-antibody sandwiches is eluted and hybridized to a sequence complementary to half of the barcode DNA on a glass slide. A DNA-probe labeled gold nanoparticle binds to the other half of the immobilized barcode DNA and silver ions are reduced by hydroquinone on the surface, amplifying the visualization of biobarcode signals. A later version of this assay replaced the microtiter 
wells with antibody-coated magnetic nanoparticles that facilitated the separation of the antigen-nanoparticle complexes from solution [36]. This biobacode technique has demonstrated promising strides toward the grand challenge of early HIV detection [35] and bears the potential for a quantitative test, yet it has not yet been shown as a suitable replacement for quantitative nucleic acid detection technologies or to have been evaluated for efficacy in resource-limited settings.

2) Detection of RT Activity: RT is an essential component of replication-competent HIV and thus a specific marker of HIV infection. The ExaVir Load assay (Cavidi Tech AB, Uppsala, Sweden), which is based on the detection of RT activity, was first described by Ekstrand et al. [38]. This assay requires pretreatment of blood plasma from HIV-positive blood and isolation of the virus on an immobilization gel column with subsequent washing to remove anti-RT antibodies or RT-inhibiting antiretroviral drugs that are present in many individuals undergoing ART [39], [40]. The sample is eluted from the immobilization column by washing with a viral lysis buffer that frees virusencapsulated RT for assay. RT activity is quantified based on incorporation of 5-bromodeoxyuridine 5' triphosphate (BrdUTP) in RT DNA product and subsequent BrdUTP tagging with an alkaline phosphate-conjugated antibody. A substrate for AP is then introduced after washing for colorimetric or fluorimetric analysis. The ExaVir assays have been evaluated for sensitivity, practicality, and flexibility among various HIV subtypes by several clinical studies, including investigations in Burkina Faso [41], Mobmasa, Kenya [31], Botswana [42], Nairobi, Kenya [43], and Johannesburg, South Africa [27]. Evaluations appear optimistic toward the potential of the ExaVir as a less-expensive alternative to PCR [26], [27], [31], [41]-[49].

3) Miniaturization of PCR, Nonquantitative: Several efforts to adapt state-of-the-art testing for resource-limited settings have involved simplification or automation of various aspects of PCR. For example, Tang et al. developed an isothermal amplification kit based on a reverse-transcriptase helicase-dependent nucleic acid amplification technique that was integrated with a vertical-flow DNA detection strip [50]. The assay, however, still required rigorous preparation of the sample in a laboratory setting, including the purification of viral RNA. Lee et al. described an isothermal simple amplification-based assay that could be performed on a table-top PoC machine including both amplification and dipstick detection [51].

Lee et al. developed a microfluidic design for on-chip RT-PCR containing mixture and reaction chambers for RT and PCR as well as a detection chamber in which amplified product is immobilized on complementary probe DNA [52]. An overview of their microfluidic PCR device is depicted in Fig. 4 [52]. An infrared lamp serves as the heart source for PCR thermo cycling and immobilized amplified PCR product is tagged with horseradish peroxidase that reacts with substrate solution to produce a chemiluminescent product for optical detection. This labon-a-chip design was capable of performing RT-PCR in $35 \mathrm{~min}$, but requires further demonstration of sufficient sensitivity and has not been analyzed for quantitative detection.

4) Miniaturization of PCR, Quantitative: Shen et al. described the application of a SlipChip device to amplification

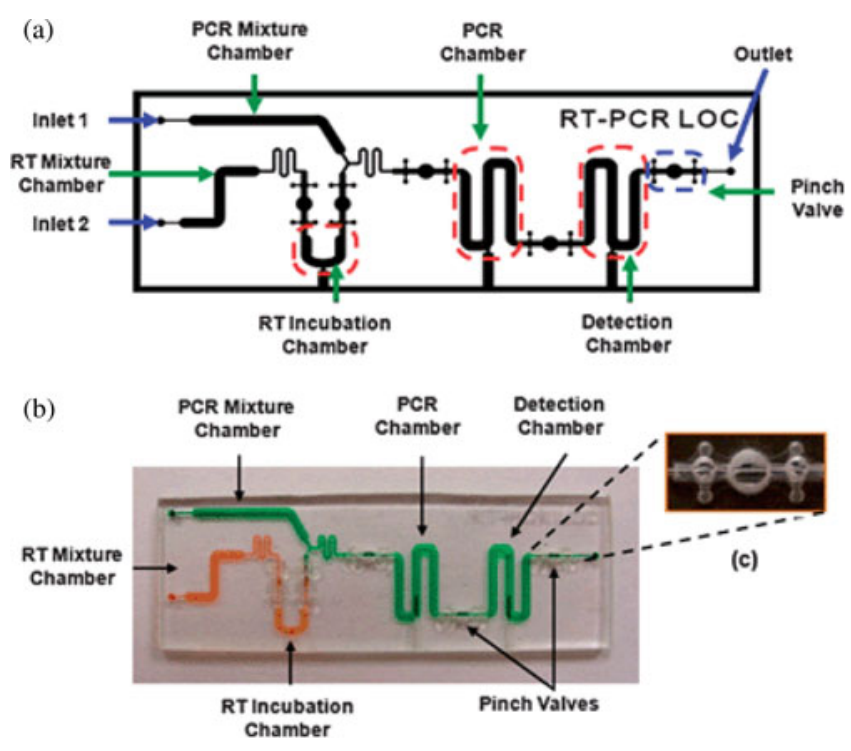

Fig. 4. Polymer-based device for on-chip PCR. Reproduced from [52] with permission from The Royal Society of Chemistry.
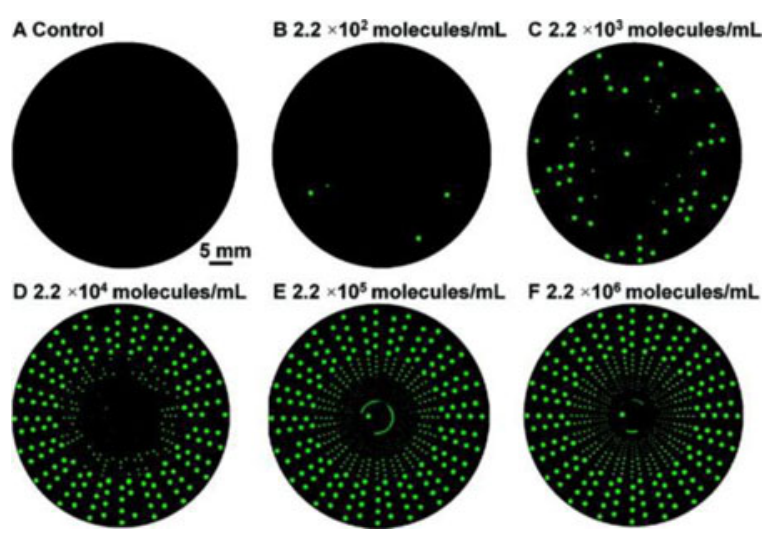

Fig. 5. Digital RT-PCR results on a rotational SlipChip. Reprinted with permission from [53]. Copyright 2011 American Chemical Society.

of HIV RNA [53]. RT-PCR mixture containing samples is introduced to 160 wells each of $1,5,25$, and $125 \mathrm{~nL}$ allowing for multiplexed analysis. Correct volumes are ensured by deadend filling facilitated by rotational slipping of a layer of the chip and digital PCR is performed, allowing quantification of viral RNA copies. Digital PCR fluorescence on the SlipChip is demonstrated in Fig. 5 [53]. Ultimately, the technique was capable of detecting 37 viral copies/mL plasma, although additional demonstration of this approach is necessary for consideration as a platform for field testing.

Rohrman et al. recently described another gold nanoparticlebased technique for the detection of amplified HIV RNA [54]. In their study, NASBA product is placed on a conjugate pad containing gold nanoparticles functionalized with complementary RNA strands that bind the sequence of interest. The sample flows laterally by capillarity down a nitrocellulose membrane strip to a detection zone in which nanoparticle-bound sequences are immobilized. An enhancement solution reduces metallic ions on the surface to increase the colorimetric result, which can be assessed with a common cell phone camera. The assay is paper 


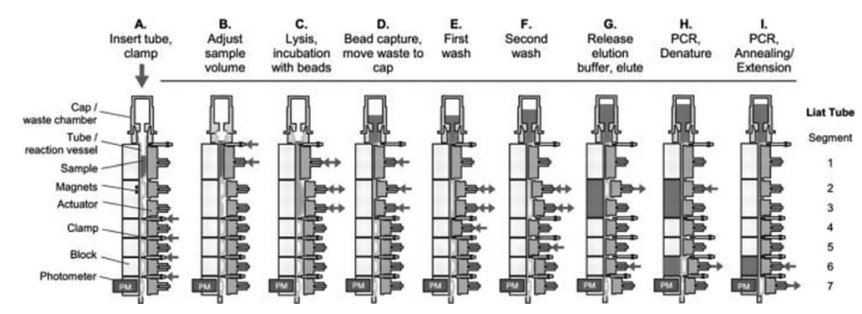

Fig. 6. Overview of Liat analyzer. Reprinted from [55] with permission from Oxford University Press.

based and is easily destroyed by incineration and is reported to cost approximately $\$ 0.80$ per strip; however, it relies on amplified nucleic acid and thus does not present a solution to some of the most fundamental challenges to implementing PCR-based technologies in resource-limited settings.

Tanriverdi et al. adapted a commercially available HIV assay to fit a portable, fully integrated, and automated diagnostic system called Liat Analyzer [55]. 200- $\mu$ L plasma is loaded into an assay tube and loaded into the analyzer that prepares the sample by performing viral lysis and nucleic acid conjugation with magnetic glass beads. The analyzer elutes the viral RNA and performs RT and PCR with real-time fluorescence detection, showing good correlation with COBAS TaqMan HIV-1 and Versant HIV-1 RNA (bDNA) assays. The full process is depicted in Fig. 6 [55]. The fully integrated test is completed in $88 \mathrm{~min}$ and exhibits a limit of detection of 1000 copies $/ \mathrm{mL}$, leaving room for improvement to compete with the most rapid and sensitive technologies.

5) Virus Isolation: In strides toward alternative (non-PCR) approaches to HIV quantification, direct capture of HIV in microfluidic flow-through devices has been demonstrated by Demirci et al. [56]-[58]. Briefly, a microfluidic chamber is functionalized with antibodies specific for the HIV envelopeassociated protein gp-120 through a variety of surface chemistry techniques and 10 [56], [57] or $100 \mu \mathrm{L}$ [58] of whole blood containing HIV was flowed through the device. Captured viruses were initially visualized with quantum-dot tags to verify capture [56], [57], but in a more recent report were lysed on-chip, collected, and interrogated by RT-qPCR for HIV nucleic acid showing $69.7-87.6 \%$ capture efficiency for a variety of subtypes and viral loads [58].

In another approach, Chen et al. mixed virus-containing plasma with superparamagnetic nanoparticles functionalized with anti-CD44, an antibody that binds HIV, and injected the sample onto a microfluidic chip with geometries designed for mixing [59]. Ferromagnetic particles in the fluidic device concentrate an external magnetic field that concentrates virus-bound particles, achieving separation from plasma. Isolated sample is then lysed and interrogated for $\mathrm{p} 24$ with an ELISA kit, revealing a maximum capture efficiency of 79\% [59]. An overview of this capture device is shown in Fig. 7 [59]. These platforms, which ultimately could be integrated in a sample-to-answer system, create the opportunity for improved sensitivity by removing the virus from whole blood or plasma and thereby eliminating contaminants that may interfere with detection.

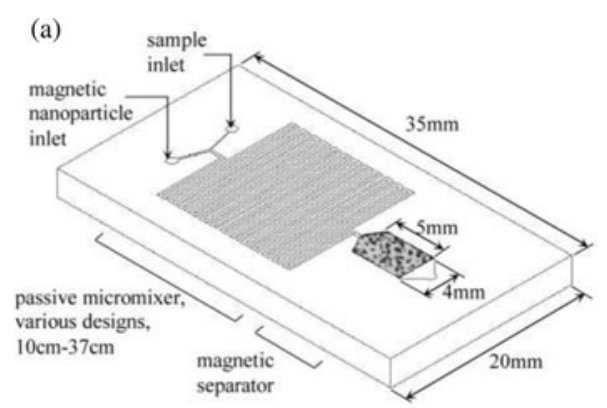

(b)

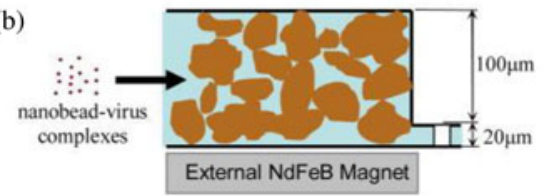

(c)

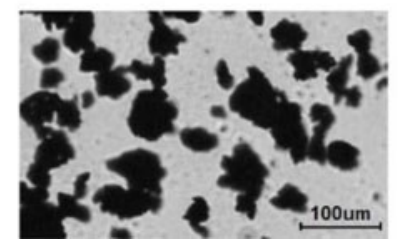

Fig. 7. Superparamagnetic nanoparticle capture device. Reprinted with permission from [59]. Copyright 2009 American Chemical Society.

\section{PROVIRAL LOAD}

\section{A. Current State of the Art}

Provirus refers to the genome of a virus directly integrated with the DNA of the host cell. The proviral load is not as ubiquitous as the plasma viral load or CD4+ T lymphocyte count in clinical management of HIV/AIDS, yet it bears certain significance as the standard for early diagnosis of infection in newborns for whom mother-to-child transmission is suspected, since serological testing is inadequate due to the possibility of false positives from the presence of passively acquired maternal antibodies [3], [60]-[66]. Many have also acknowledged that the proviral load may be an opportunity for early detection in adults in the 2-8 week window period [67] before seroconversion [61]-[63], a useful alternative for monitoring of ART when plasma RNA levels are undetectable [61], [68], [69], or a complement to the plasma RNA load for diagnostic or prognostic purposes [61], [68], [70]-[73]. Laboratory techniques for detection of proviral DNA have been described including nonquantitative PCR approaches [64], [74], quantitative PCR approaches [14], [61], [68], [69], [75], [76], electrochemiluminescencebased detection of PCR products [62], enzyme immunoassay detection of PCR products [63], and one study which performed PCR analysis on dried blood spots [60].

\section{B. Global Health Solutions}

Jangam et al. presented a solution to the challenges of sample preparation in resource-limited settings when analyzing proviral load with a low-cost extraction technique called filtration isolation of nucleic acids (FINA) [77]. In this technique, whole blood is introduced on a membrane disk and subsequently washed with 
$\mathrm{NaOH}$ resulting in isolation of genomic DNA on the membrane. The membrane is then placed directly in a PCR reaction mix for quantitative analysis. Recently, the same group has reported integration of this extraction method with a sample-to-answer PoC PCR system for proviral DNA detection [78]. In this case, blood collected from a heel prick is lysed in the blood collection device, applied to a separator module for FINA, and inserted into an injection-molded assay card. The assay card contains reagents for PCR prepackaged in a foil laminate reagent reservoir and the entire card it inserted directly into a table-top instrument which performs reagent delivery, thermal cycling, and fluorescence detection. The estimated cost of the instrumentation is $\$ 3000.00$, while each disposable assay card is expected to cost $\$ 50.00$ or less, a per-test cost on the higher end of the range of estimates reported in the approaches discussed in this paper.

Wang et al. have also recently described a device capable of proviral DNA detection on a chip [79]. In this proof of concept, HIV-infected T cells were loaded onto the chip where they were first heat-lysed and then hybridized with nucleotide probeconjugated magnetic beads. A permanent magnet was then used to immobilize probes, while debris was cleared with a vacuum and the sample was washed. Purified sample was then split between four separate chambers containing unique primer pairs, and PCR amplification was performed and monitored by SYBR Green I fluorescence and integrated optical detection. The whole process was completed in $95 \mathrm{~min}$, demonstrating potential for implementation as a PoC device in resource-limited settings, although demonstration of this technique from whole-blood input would be necessary for truly PoC applications.

\section{CD4+ T LYMPHOCYTE COUNT}

\section{A. Current State of the Art}

The current gold standard for enumeration of CD4+ T lymphocytes involves immune staining and analysis of cells with a flow cytometer, a technique that not only requires expensive and bulky instrumentation but also highly trained laboratory technicians. In efforts to bring CD4 enumeration to resource-limited settings, various techniques have been employed. Here, we organize various technologies for CD4 enumeration in resourcelimited settings based on the following categories: optical detection methods, electrical detection methods, technologies based on microcytometry employing either optical or electrical techniques, catch-and-release devices, and instrument-free methods.

\section{B. Global Health Solutions}

1) Optical Methods: Many efforts have used fluorescent tagging and subsequent image processing to automatically enumerate CD4+ T lymphocytes in microchambers. Some designs relied on the even distribution of cells in a plastic chamber to produce accurate counts [80]. Others have used a microfabricated membrane to filter out erythrocytes, leaving leukocytes, which were fluorescently labeled [81]. Specialized image processing algorithms have been developed for the analysis of images from such devices [82]. Thorslund et al. developed and refined a bioactivated PDMS device for capture of CD4+ cells and subsequent imaging with HOECHST and CD3-FITC [83], [84]. Fluorescence detection was later enhanced by using quantum dots [85], [86], forming the technology behind LabNow, Inc.

Another approach used immunospecific paramagnetic beads to bring fluorescently labeled CD4 $+\mathrm{T}$ cells into the focusing plane for analysis, reducing counting error [87]-[89]. Cheng et al. have investigated CD4 $+\mathrm{T}$ cell capture by controlling shear stresses at the chamber walls and enumerating cells using a cocktail of fluorescently labeled antibodies [90], [91]. They improved their design by including a monocyte depletion chamber to reduce the positive bias created at lower CD4+ T cell concentrations [92].

Beck et al. have eliminated the off-chip labeling step required by the aforementioned methods by coating capture chambers with hydrogels containing fluorescent antibodies and drying them for storage [93]. During testing, blood enters the capture region, causing the hydrogel to swell and release the antibodies, specifically labeling CD4+ and CD8 + T cells. Subsequent fluorescent image cytometry is used to obtain the CD4+ and CD8 + T cell counts. The Alere Pima CD4 counter uses a similar method to label CD4+ T cells using cartridges containing a lyophilized antibody pellet [93], [94], and has shown some success in field testing including sites in Harare, Zimbabwe [95], Maputo, Mozambique [96], Gauteng Province, South Africa [97], Kampala, Uganda [98], and London, U.K. [99]. However, in some situations, it has operational costs similar to or more expensive than standard lab flow cytometric analysis [97], [100].

The aforementioned optical methods require the use of lenses and focusing to analyze samples, but this can increase the cost and decrease the portability of the device and several technologies have made attempts at simplifying the optical component. Gohring and Fan quantified the antibody-mediated attachment of T cells by the amount of shift in the whispering gallery mode of an optofluidic ring resonator [101]. Moon et al. counted immobilized helper $\mathrm{T}$ cells by their shadows cast over a chargecoupled device (CCD) by a white light source [102], [103]. Wang et al. further simplified the optics by not requiring an external light source: immobilized CD4+ T cells were labeled with CD3-conjugated horseradish peroxidase to facilitate a chemiluminescent reaction, which was amplified and quantified by a photodetector [104]. This device was tested using samples from patients at a treatment center in Dar es Salaam, Tanzania [105].

2) Electrical Methods: Electrical methods for enumerating CD4+ T lymphocytes are promising due to the fact that they would not require optical components such as lenses, filters, light sources, photodetectors, and CCDs, which can be expensive, bulky, fragile, and require periodic maintenance. An electrical PoC solution could require only solid-state components to electrically interrogate a sensing geometry, process sensor output, and provide input from and results to the user.

Mishra et al. used three-electrode cyclic voltammetry to estimate the number of CD4 $+\mathrm{T}$ cells that were selectively captured on a working electrode [106], [107]. Jiang and Spencer have used this design as a building block to create an array of 200 of these electrochemical sensing regions, or pixels, conjugated 

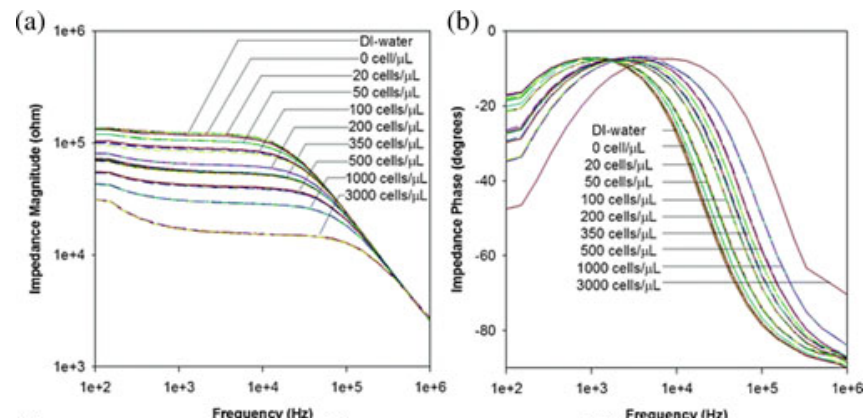

(c)

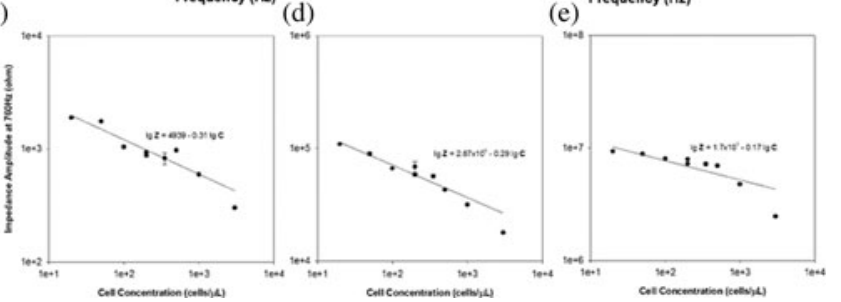

Fig. 8. Cell lysate impedance spectroscopy for enumeration of CD4 T lymphocytes. Reprinted from [109] with permission from The Royal Society of Chemistry.

with CD4 antibody. A pixel would be considered on when a CD4 $+\mathrm{T}$ cell was captured, and a total cell count was the total number of on pixels [108].

Cheng et al. enhanced their CD4+ T cell capture device [90], [91] by integrating impedance spectroscopy sensing into the capture channel to monitor cell lysate [109]. T cells from whole blood were captured on-chip and lysed in a low-conductivity buffer, releasing intracellular ions into the bulk solution, thereby changing its conductance, which increased proportionally with cell concentration. Impedance-phase spectra and correlation with cell concentration are shown in Fig. 8 [109]. The authors were able to correlate cell concentration with channel conductance with a detection sensitivity of 20 cells $/ \mu \mathrm{L}$, eliminating the need of a microscope and manual cell counting. Daktari Diagnostics, Inc., has developed the Daktari CD4 counting platform based on this technology.

The lysate impedance method has shown to be an extremely promising technology to penetrate into resource poor regions, as it requires no off-chip sample preparation, employs an electrical interrogation method, and is simple to operate. However, inherent drawbacks from measuring lysate impedance may reduce its efficacy. This technology assumes that $\mathrm{T}$ cells from various individuals contain similar ion concentrations, which may not be true, resulting in counting error. In addition, since the technology is sensitive to the concentration of ions, contamination from the sensor chip's materials and failure to wash away excess ions may reduce the system's counting resolution and dynamic range.

3) Microcytometer Approach: Kiesel et al. worked toward the goal of a compact flow cytometer with a spatial modulation technique for CD4 identification [110]. Wang et al. have developed a microfluidic chip that first labels CD4+ and CD8 $+\mathrm{T}$ lymphocytes (from buffy coat samples) on-chip using pneumatic vortexing before hydrodynamically focusing and laser-induced fluorescence (LIF) counting [111]. They were able to produce
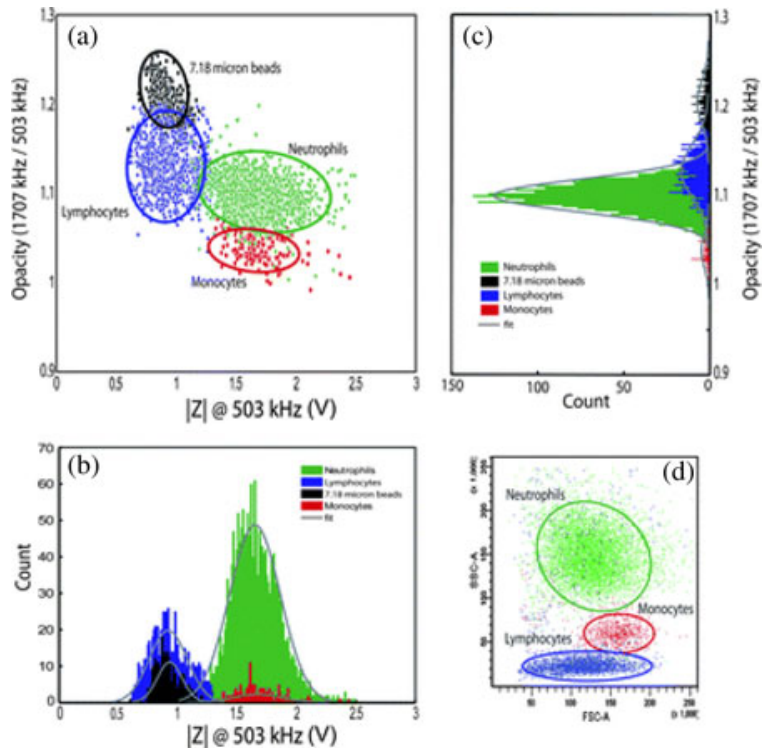

Fig. 9. Leukocyte type differentiation by dual-frequency impedance characteristics. Reprinted from [117] with permission from The Royal Society of Chemistry.

CD4/CD8 $\mathrm{T}$ cell ratios similar to that found using standard flow cytometry. Yun et al. developed a microfluidic flow cytometer enhanced by FITC-doped silica nanoparticles that required only a single detector [112]. Mao et al. designed a microfluidic flow cytometer with 3-D hydrodynamic focusing of CD4+ T lymphocytes and LIF detection [113].

Wang et al. integrated a commercial MOSFET with optical fluorescence detection to determine the percent of CD4+ T cells among a total population of lymphocytes [114]. They have also created a similar system replacing the MOSFET with a twostage differential amplification system [115], [116]. However, the added complexity of integrating both electrical and optical measurement systems may be prohibitive for PoC applications.

Holmes et al. have developed an electrical microcytometer that can differentiate between different leukocyte subtypes, such as lymphocytes, monocytes, and neutrophils, solely on their impedance characteristics at two different frequencies, as depicted in Fig. 9 [117], [118]. They were subsequently able to enhance electrical differentiation of CD4 $+\mathrm{T}$ cells from other leukocytes by specifically attaching $2.2 \mu \mathrm{m}$ CD4 antibody conjugated latex beads to the $\mathrm{T}$ cells to modify their high- and low-frequency characteristics [119]. They showed good correlation between their electrical chip-based method and the flow cytometry standard for the percentages of CD4 $+\mathrm{T}$ cells in white blood cell populations. However, the off-chip bead labeling steps they used would need to be integrated into the chip itself for this technology to be practical in resource-poor applications - a task that is difficult to perform in the laminar flow regime found at the microscale.

Watkins et al. developed an impedance-based microcytometer for determining CD4 $\mathrm{T}$ cell counts employing a resistive pulse technique [120]. Cells were initially focused in a 3-D flow sheath for one-by-one flow past a pair of coplanar electrodes and subsequent analysis of ac impedance indicated cell passage by 

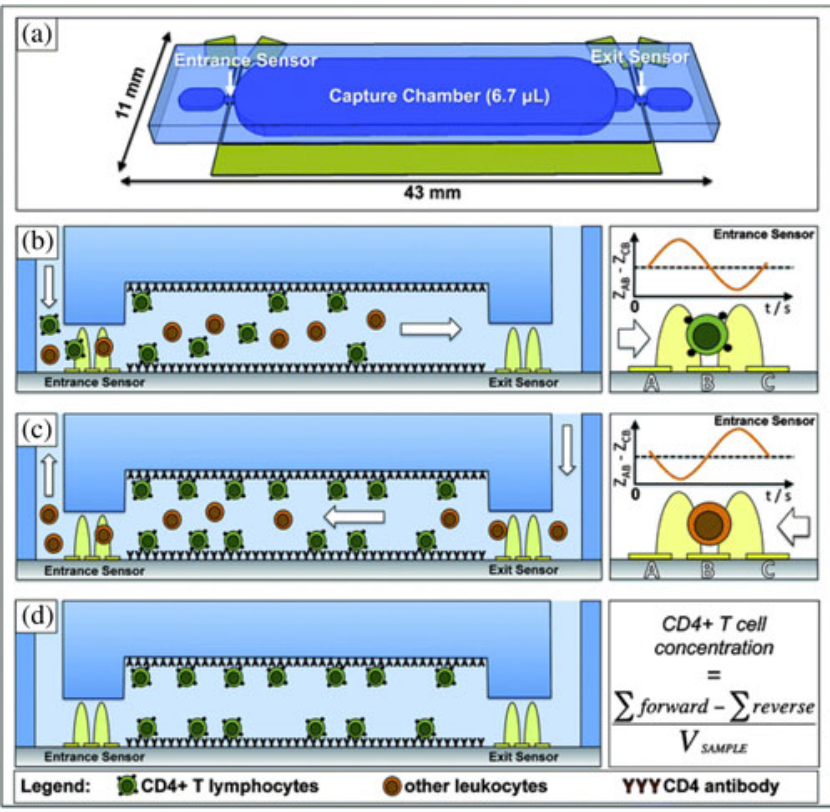

Fig. 10. Differential counter technique for CD4 $+\mathrm{T}$ cell enumeration Reprinted from [121] with permission from The Royal Society of Chemistry.

an impedance pulse. A coplanar three-electrode configuration was implemented in a later device that incorporated entrance and exit counting as white blood cells were passed through an antiCD4 antibody-functionalized capture chamber, as illustrated in Fig. 10 [121]. CD4+ T cells were depleted from the sample by immobilization in the capture chamber and the absolute CD4 count was provided by the difference between entrance and exit counts.

4) Catch and Release: Chemical release of CD4+ T cells postcapture has proven to be more difficult, as the cells may further bond to the substrate nonspecifically through membrane adhesion molecules. Zhu et al. have shown the capture and release of $\mathrm{CD} 4+\mathrm{T}$ cells using electrochemical reactions on microfabricated electrodes; however, some drawbacks are that some cell death occurs after $\mathrm{T}$ cell release $(\sim 10 \%)$ and agitation is needed to assist in electrochemical desorption, which is more difficult in the laminar flow regime found in a closed microfluidic chamber [122], [123]. In addition, mass production may be hindered by the fact that the capture region is limited to the area defined by the electrodes, requiring a PEG gel passivation layer elsewhere to prevent nonspecific cell capture.

Gurkan et al. used a temperature responsive polymer to capture and release CD4+ T cells [124]. A capture chamber coated with poly (N-isopropylacrylamide) (PNIPAAm) was immobilized with CD4 antibody-Neutravidin complexes at $37^{\circ} \mathrm{C}-$ when the polymer is hydrophobic and prefers interactions with the Neutravidin. CD4+ T cells are captured at the same temperature before washing away unbound cells and lysing erythrocytes. The CD4+ T cells are released by decreasing the chip's temperature below $32^{\circ} \mathrm{C}$, when the PNIPAAm layer becomes hydrophilic, releasing the antibody-Neutravidin complexes and thereby releasing the $\mathrm{CD} 4+\mathrm{T}$ cells. They were able to release $59 \%$ of captured CD4+ T cells with high viability (94\%).
This method needs to address a few challenges before being a practical PoC device. This includes ensuring surface chemistry is preserved from manufacture to test (i.e., storing the chips at $\sim 37^{\circ} \mathrm{C}$ ) and improving the release efficiency for accurate CD4+ T cell enumeration.

5) Instrument-Free Methods: Since 2005, the Bill and Melinda Gates Foundation has been funding a CD4 initiative (centered at Imperial College London) to create simple, powerfree CD4+ T cell counting technologies that would lessen costs and increase penetration into resource-poor regions [125]. A semiquantitative immunochromatographic strip (ICS) being developed by The Burnet Institute compares the intensity of gold particles that are specifically attached to CD4+ T cells at a CD4 capture strip to a reference strip which has a similar intensity to a known concentration of CD4+ T cells [126]. Zyomyx has developed a device that uses the sedimentation of high-density CD4 antibody-conjugated beads to estimate the concentration of CD4+ T cells from whole blood samples [126], [127]. These beads specifically attach to the $\mathrm{CD} 4+\mathrm{T}$ cells and are sedimented with the help of a manually powered centrifuge. The height of sedimentation in the column is proportional to the concentration of $\mathrm{CD} 4+\mathrm{T}$ cells, and is viewed through a window and compared to calibrated markings to give the CD4 $+\mathrm{T}$ cell count. The device also contains a chamber that used CD14conjugated magnetic particles and a magnetic collar to deplete monocytes before the sedimentation step. These semiquantitative instrument-free methods may be viewed as short-term solutions, but fullyquantitative micro- and nanotechnology solutions promise more precise and user-friendly approaches.

\section{CONCLUSION}

The United Nations reports that recent progress toward grand challenges in HIV/AIDS has primarily taken the form of record increases in accessibility of treatment worldwide [2], leading to decreased HIV prevalence and mortality. The global state of AIDS, however, is far from the target highlighted by the United Nations of zero new HIV infections [128]. Until a vaccine or a cure can be developed, $\mathrm{PoC}$ testing will be a critical factor in controlling the epidemic and reversing the spread of HIV. Key studies have shown that viral load is a chief determinant of risk of transmission [129]. With viral load suppression a primary goal of ART, it follows that regular testing, which enables effective management of HIV in people currently living with the disease, must be an essential component of the global strategy.

The emergence of biomicro- and bionanotechnology in the past few decades has introduced new techniques for fluid handling and cell and biomolecule manipulation and identification, enabling highly sensitive interrogation of small sample volumes and setting the foundation for innovation in PoC diagnostics. Most encouraging is the development of techniques capable of performing analysis from whole blood input without any requirement for manual preparation or pretreatment. Furthermore, technologies which couple automated sample processing with electrical biosensor techniques impart hope that a holistic solution to practical PoC needs is being realized. 
The Millennium Development Goals have set a target to not only halt the spread of HIV/AIDS but to reverse its spread by 2015 [2]. If this milestone is to be realized, it will involve a concerted effort requiring the collaboration of world leaders, policymakers, community leaders, healthcare providers, and many others. But it is certain that these goals will not be reached if those at the forefront of combating the HIV/AIDS epidemic are not equipped with the proper tools for their mission. It is here that we look to these recent innovations in cell counting and virus quantification to rise to this grand challenge in global health.

\section{REFERENCES}

[1] WHO, UNAIDS, and UNICEF, "Global HIV/AIDS Response: Epidemic update and health sector progress towards Universal Access," 2011.

[2] United Nations, "The Millennium Development Goals Report 2012," 2012.

[3] J. A. Aberg, J. E. Kaplan, H. Libman, P. Emmanuel, J. R. Anderson, V. E. Stone, J. M. Oleske, J. S. Currier, and J. E. Gallant, "Primary care guidelines for the management of persons infected with human immunodeficiency virus: 2009 update by the HIV medicine association of the infectious diseases society of America," Clin. Infect. Dis., vol. 49, no. 5, pp. 651-681, Sep. 2009

[4] F. H. Epstein, G. Pantaleo, C. Graziosi, and A. S. Fauci, "The immunopathogenesis of human immunodeficiency virus infection," New Engl.J. Med., vol. 328, no. 5, pp. 327-335, Feb. 1993.

[5] National Institute of Allergy and Infectious Diseases, "The relationship between the human immunodeficiency virus and the acquired immunodeficiency syndrome," HIV/AIDS, 2010. [Online]. Available: http://www. niaid.nih.gov/topics/hivaids/understanding/howhivcausesaids/pages/ relationshiphivaids.aspx

[6] W. H. Organization, "Antiretroviral therapy for HIV infection in adults and adolescents," 2010.

[7] E. M. Krantz, K. H. Hullsiek, J. F. Okulicz, A. C. Weintrob, B. K. Agan, N. F. Crum-Cianflone, A. Ganesan, T. M. Ferguson, and B. R. Hale, "Elevated CD8 counts during HAART are associated with HIV virologic treatment failure," J. Acquir. Immune Defic. Syndr., vol. 57, no. 5, pp. 396-403, Aug. 2011.

[8] N. L. Michael, T. Mo, A. Merzouki, M. O. Shaughnessy, C. Oster, D. S. Burke, R. R. Redfield, and D. L. Birx, "Human immunodeficiency virus type 1 Cellular RNA load and splicing patterns predict disease progression in a longitudinally studied cohort," J. Virol., vol. 69, no. 3, pp. 1868-1877, 1995.

[9] K. Saksela, C. Stevens, and P. Rubinstein, "HIV-1 messenger RNA in peripheral blood mononuclear cells as an early marker of risk for progression to AIDS," Ann. Internal Med., vol. 123, no. 9, pp. 641-648, 1995.

[10] A. O. Pasternak, S. Jurriaans, M. Bakker, B. Berkhout, and V. V Lukashov, "Steady increase in cellular HIV-1 load during the asymptomatic phase of untreated infection despite stable plasma viremia," AIDS, vol. 24, no. 11, pp. 1641-1649, Jul. 2010.

[11] M. R. Furtado and L. A. Kingsley, "Changes in the viral mRNA expression pattern correlate with a rapid rate of $\mathrm{CD} 4+\mathrm{T}$-cell number decline in human immunodeficiency virus type 1 -infected individuals. Changes in the viral mRNA expression pattern correlate with a rapid rate of CD4+ T-cell," 1995.

[12] A. O. Pasternak, S. Jurriaans, M. Bakker, J. M. Prins, B. Berkhout, and V. V Lukashov, "Cellular levels of HIV unspliced RNA from patients on combination antiretroviral therapy with undetectable plasma viremia predict the therapy outcome," PLOS ONE, vol. 4, no. 12, pp. 1-10, Dec. 2009.

[13] M. Zanchetta, S. Walker, N. Burighel, D. Bellanova, O. Rampon, C. Giaquinto, and A. De Rossi, "Long-term decay of the HIV-1 Reservoir in HIV-1 - infected children treated with highly active antiretroviral therapy," J. Infect. Dis., vol. 193, pp. 1718-1727, 2006.

[14] A. O. Pasternak, K. W. Adema, M. Bakker, S. Jurriaans, B. Berkhout, M. Cornelissen, and V. V. Lukashov, "Highly sensitive methods based on seminested real-time reverse transcription-PCR for quantitation of human immunodeficiency virus type 1 unspliced and multiply spliced RNA and proviral DNA," J. Clin. Microbiol., vol. 46, no. 7, pp. 22062211, Jul. 2008
[15] R. S. Soares, P. Matoso, M. Calado, and A. E. Sousa, "Strategies to quantify unspliced and multiply spliced mRNA expression in HIV-2 infection," J. Virol. Methods, vol. 175, no. 1, pp. 38-45, Jul. 2011.

[16] S. H. Vermund, "Chapter 1: HIV Epidemic," in Challenges in Infectious Diseases, I. W. Fong, Ed. New York, NY, USA: Springer, 2013, pp. 3 46.

[17] U.S. Food and Drug Administration, "Complete list of donor screening assays for infectious agents and HIV diagnostic assays." (2011). [Online]. Available: http://www.fda.gov/biologicsbloodvaccines/ bloodbloodproducts/approvedproducts/licensedproductsblas/ blooddonorscreening/infectiousdisease/ucm080466.htm

[18] U.S. Food and Drug Administration, (2010). Vaccines, blood \& biologics approved products: HIV-1 [Online]. Available: http://www.fda. gov/BiologicsBloodVaccines/BloodBloodProducts/ApprovedProducts/ LicensedProductsBLAs/BloodDonorScreening/InfectiousDisease/ucm 126582.htm

[19] T. Peterson, and M. Stuart. (2011). "PCR HIV test," Medscape Reference [Online]. Available: http://emedicine.medscape.com/article/1983649overview

[20] U.S. Food and Drug Administration and R. Klein, "Three new HIV assays approved," 2007.

[21] C. Garrido, N. Zahonero, A. Corral, M. Arredondo, V. Soriano, and C. de Mendoza, "Correlation between human immunodeficiency virus type 1 (HIV-1) RNA measurements obtained with dried blood spots and those obtained with plasma by use of Nuclisens EasyQ HIV-1 and Abbott RealTime HIV load tests," J. Clin. Microbiol., vol. 47, no. 4, pp. 10311036, Apr. 2009.

[22] A. Johannessen and C. Garrido, "Dried blood spots perform well in viral load monitoring of patients who receive antiretroviral treatment in rural Tanzania," Clin. Infect. Dis., vol. 49, pp. 976-981, 2009.

[23] S. Cassol, M. Gill, and R. Pilon, "Quantification of human immunodeficiency virus type 1 RNA from dried plasma spots collected on filter paper," J. Clin. Microbiol., vol. 35, pp. 2795-2801, 1997.

[24] P. Mwaba, S. Cassol, A. Nunn, and R. Pilon, "Whole blood versus plasma spots for measurement of HIV-1 viral load in HIV-infected African patients," Lancet, vol. 362, no. 9401, pp. 2067-2068, Dec. 2003.

[25] R. de la Rica, M. M. Stevens, "Plasmonic ELISA for the ultrasensitive detection of disease biomarkers with the naked eye," Nature Nanotechnol., vol. 7, pp. 821-824, Oct. 2012.

[26] C. Jennings and S. Fiscus, "Comparison of two human immunodeficiency virus (HIV) RNA surrogate assays to the standard HIV RNA assay," $J$. Clin. Microbiol., vol. 43, pp. 5950-5956, 2005.

[27] G. Stevens and N. Rekhviashvili, "Evaluation of two commercially available, inexpensive alternative assays used for assessing viral load in a cohort of human immunodeficiency virus type 1 subtype c-infected patients from South Africa," J. Clin. Microbiol., vol. 43, no. 2, pp. 857-861, Feb. 2005.

[28] S. A. Fiscus, J. Wiener, E. J. Abrams, M. Bulterys, A. Cachafeiro, and R. A. Respess, "Ultrasensitive p24 antigen assay for diagnosis of perinatal human immunodeficiency virus type 1 infection," J. Clin. Microbiol., vol. 45, no. 7, pp. 2274-2277, Jul. 2007.

[29] R. Respess and A. Cachafeiro, "Evaluation of an ultrasensitive p24 antigen assay as a potential alternative to human immunodeficiency virus type 1 RNA viral load assay in resource-limited settings," J. Clin. Microbiol., vol. 43, pp. 506-508, 2005.

[30] D. Bonard, F. Rouet, T. Toni, and A. Minga, "Field evaluation of an improved assay using a heat-dissociated p24 antigen for adults mainly infected with HIV-1 CRF02_AG strains in Cote d'Ivoire, West Africa," J. Acquir. Immune Defic. Syndr., vol. 34, pp. 267-273, 2003.

[31] K. Steegen, S. Luchters, N. De Cabooter, J. Reynaerts, K. Mandaliya, J. Plum, W. Jaoko, C. Verhofstede, and M. Temmerman, "Evaluation of two commercially available alternatives for HIV-1 viral load testing in resource-limited settings," J. Virol. Methods, vol. 146, no. 1-2, pp. 178 187, Dec. 2007.

[32] K.-B. Lee, E.-Y. Kim, C. A. Mirkin, and S. M. Wolinsky, "The use of nanoarrays for highly sensitive and selective detection of human immunodeficiency virus type 1 in plasma," Nano Lett., vol. 4, no. 10, pp. 1869-1872, Oct. 2004.

[33] Z. A. Parpia, R. Elghanian, A. Nabatiyan, D. R. Hardie, and D. M. Kelso, "p24 antigen rapid test for diagnosis of acute pediatric HIV infection," J. Acquir. Immune Defic. Syndr., vol. 55, no. 4, pp. 413-419, Dec. 2010.

[34] S. Tang, J. Zhao, and J. Storhoff, "Nanoparticle-based biobarcode amplification assay (BCA) for sensitive and early detection of human immunodeficiency type 1 capsid (p24) antigen," J. Acquir. Immune Defic. Syndr., vol. 46, no. 2, pp. 231-237, Oct. 2007. 
[35] S. Tang and I. Hewlett, "Nanoparticle-based immunoassays for sensitive and early detection of HIV-1 capsid (p24) antigen," J. Infect. Dis., vol. 201, no. Suppl. 1, pp. S59-S64, Apr. 2010.

[36] E. Kim, J. Stanton, and B. Korber, "Detection of HIV-1 p24 Gag in plasma by a nanoparticle-based bio-barcode-amplification method," Nanomedicine, vol. 3, no. 3, pp. 293-303, 2008.

[37] J. Nam, C. Thaxton, and C. Mirkin, "Nanoparticle-based bio-bar codes for the ultrasensitive detection of proteins," Science, vol. 301, no. 5641, pp. 1884-1886, Sep. 2003.

[38] D. H. Ekstrand, R. J. Awad, C. F. Källander, and J. S. Gronowitz, "A sensitive assay for the quantification of reverse transcriptase activity based on the use of carrier-bound template and non-radioactive-product detection, with special reference to human-immunodeficiency-virus isolation," Biotechnol. Appl. Biochem., vol. 23 (Pt 2), pp. 95-105, Apr. 1996.

[39] A. Malmsten, X.-W. Shao, K. Aperia, G. E. Corrigan, E. Sandström, C. F. R. Källander, T. Leitner, and J. S. Gronowitz, "HIV-1 viral load determination based on reverse transcriptase activity recovered from human plasma," J. Med. Virol., vol. 71, no. 3, pp. 347-359, Nov. 2003.

[40] A. Malmsten, X.-W. Shao, S. Sjödahl, E.-L. Fredriksson, I. Pettersson, T. Leitner, C. F. R. Källander, E. Sandström, and J. S. Gronowitz, "Improved HIV-1 viral load determination based on reverse transcriptase activity recovered from human plasma," J. Med. Virol., vol. 76, no. 3, pp. 291-296, Jul. 2005.

[41] J. Lombart, M. Vray, and A. Kafando, "Plasma virion reverse transcriptase activity and heat dissociation-boosted p24 assay for HIV load in Burkina Faso, West Africa," Aids, vol. 19, pp. 1273-1277, 2005.

[42] M. Mine, K. Bedi, T. Maruta, D. Madziva, M. Tau, T. Zana, T. Gaolathe, S. Moyo, K. Seipone, N. Ndwapi, M. Essex, and R. Marlink, "Quantitation of human immunodeficiency virus type 1 viral load in plasma using reverse transcriptase activity assay at a district hospital laboratory in Botswana: A decentralization pilot study," J. Virol. Methods, vol. 159, no. 1, pp. 93-97, Jul. 2009.

[43] V. Greengrass, B. Lohman, L. Morris, M. Plate, P. M. Steele, J. L. Walson, and S. M. Crowe, "Assessment of the low-cost cavidi exavir load assay for monitoring HIV viral load in pediatric and adult patients," J. Acquir. Immune Defic. Syndr., vol. 52, no. 3, pp. 387-390, Nov. 2009.

[44] J. Braun, J.-C. Plantier, M.-F. Hellot, E. Tuaillon, M. Gueudin, F. Damond, A. Malmsten, G. E. Corrigan, and F. Simon, "A new quantitative HIV load assay based on plasma virion reverse transcriptase activity for the different types, groups and subtypes," AIDS, vol. 17, no. 3, pp. 331-336, Feb. 2003.

[45] S. Sivapalasingam and S. Essajee, "Human immunodeficiency virus (HIV) reverse transcriptase activity correlates with HIV RNA load: Implications for resource-limited settings," J. Clin. Microbiol., vol. 43, pp. 3793-3796, 2005.

[46] H. S. Iqbal, P. Balakrishnan, A. J. Cecelia, S. Solomon, N. Kumarasamy, V. Madhavan, K. G. Murugavel, A. K. Ganesh, S. S. Solomon, K. H. Mayer, and S. M. Crowe, "Use of an HIV-1 reverse-transcriptase enzyme-activity assay to measure HIV-1 viral load as a potential alternative to nucleic acid-based assay for monitoring antiretroviral therapy in resource-limited settings," J. Med. Microbiol., vol. 56, no. 12, pp. 16111614, Dec. 2007.

[47] V. L. Greengrass, M. M. Plate, P. M. Steele, J. T. Denholm, C. L. Cherry, L. M. Morris, A. Hearps, and S. M. Crowe, "Evaluation of the Cavidi ExaVir Load assay (version 3) for plasma human immunodeficiency virus type 1 load monitoring," J. Clin. Microbiol., vol. 47, no. 9, pp. 30113013, Sep. 2009.

[48] W. Labbett, A. Garcia-Diaz, Z. Fox, G. S. Clewley, T. Fernandez, M. Johnson, and A. M. Geretti, "Comparative evaluation of the ExaVir Load version 3 reverse transcriptase assay for measurement of human immunodeficiency virus type 1 plasma load," J. Clin. Microbiol., vol. 47, no. 10, pp. 3266-3270, Oct. 2009.

[49] P. Stewart, A. Cachafeiro, S. Napravnik, J. J. Eron, I. Frank, C. van der Horst, R. J. Bosch, D. Bettendorf, P. Bohlin, and S. A. Fiscus, "Performance characteristics of the Cavidi ExaVir viral load assay and the ultra-sensitive P24 assay relative to the Roche Monitor HIV-1 RNA assay," J. Clin. Virol., vol. 49, no. 3, pp. 198-204, Nov. 2010.

[50] W. Tang, W. H. A. Chow, Y. Li, H. Kong, Y.-W. Tang, and B. Lemieux, "Nucleic acid assay system for tier II laboratories and moderately complex clinics to detect HIV in low-resource settings," J. Infect. Dis., vol. 201, no. Suppl 1, pp. S46-S51, Apr. 2010.

[51] H. H. Lee, M. A. Dineva, Y. L. Chua, A. V Ritchie, I. Ushiro-Lumb, and C. A. Wisniewski, "Simple amplification-based assay: A nucleic acid- based point-of-care platform for HIV-1 testing," J. Infect. Dis., vol. 201, no. Suppl 1, pp. S65-S72, Apr. 2010.

[52] S. H. Lee, S.-W. Kim, J. Y. Kang, and C. H. Ahn, "A polymer lab-ona-chip for reverse transcription (RT)-PCR based point-of-care clinical diagnostics," Lab Chip, vol. 8, no. 12, pp. 2121-2127, Dec. 2008.

[53] F. Shen, B. Sun, J. E. Kreutz, E. K. Davydova, W. Du, P. L. Reddy, L. J. Joseph, and R. F. Ismagilov, "Multiplexed quantification of nucleic acids with large dynamic range using multivolume digital RT-PCR on a rotational SlipChip tested with HIV and hepatitis C viral load," J. Amer. Chemical Soc., vol. 133, no. 44, pp. 17705-17712, Nov. 2011.

[54] B. A. Rohrman, V. Leautaud, E. Molyneux, and R. R. Richards-Kortum, "A Lateral Flow assay for quantitative detection of amplified HIV-1 RNA," PLOS ONE, vol. 7, no. 9, pp. 1-8, Sep. 2012.

[55] S. Tanriverdi, L. Chen, and S. Chen, "A rapid and automated sample-toresult HIV load test for near-patient application," J. Infect. Dis., vol. 201, no. Suppl 1, pp. S52-S58, Apr. 2010.

[56] Y.-G. Kim, S. Moon, D. R. Kuritzkes, and U. Demirci, "Quantum dotbased HIV capture and imaging in a microfluidic channel," Biosens. Bioelectron., vol. 25, no. 1, pp. 253-258, Sep. 2009.

[57] S. Wang, A. Ip, F. Xu, F. F. Giguel, S. Moon, A. Akay, D. R. Kuritzkes, and U. Demirci, "Development of a microfluidic system for measuring HIV-1 viral load," Defense, vol. 7666, pp. 76661H-1-76661H-6, 2010.

[58] S. Wang, M. Esfahani, U. A. Gurkan, F. Inci, D. R. Kuritzkes, and U. Demirci, "Efficient on-chip isolation of HIV subtypes," Lab Chip, vol. 12, pp. 1508-1515, Mar. 2012.

[59] G. Chen, C. J. Alberts, W. Rodriguez, and M. Toner, "Concentration and purification of human immunodeficiency virus type 1 virions by microfluidic separation of superparamagnetic nanoparticles," Anal. Chem., vol. 82, no. 2, pp. 723-728, Jan. 2010.

[60] S. Cassol, A. Butcher, and S. Kinard, "Rapid screening for early detection of mother-to-child transmission of human immunodeficiency virus type 1," J. Clin. Microbiol., vol. 32, pp. 2641-2645, 1994.

[61] J. Weidner, U. Cassens, W. Göhde, W. Sibrowski, G. Odaibo, D. Olaleye, D. Reichelt, and B. Greve, "An improved PCR method for detection of HIV-1 proviral DNA of a wide range of subtypes and recombinant forms circulating globally," J. Virol. Methods, vol. 172, no. 1-2, pp. 22-26, Mar. 2011.

[62] T. E. Schutzbank and J. Smith, "Detection of human immunodeficiency virus type 1 proviral DNA by PCR using an electrochemiluminescencetagged probe," J. Clin. Microbiol., vol. 33, no. 8, pp. 2036-2041, Aug. 1995.

[63] D. Zella, A. Cavicchini, and E. Cattaneo, "Utilization of a DNA enzyme immunoassay for the detection of proviral DNA of human immunodeficiency virus type 1 by polymerase chain reaction," Clin. Diagn. Virol., vol. 3, no. 2, pp. 155-164, Feb. 1995.

[64] K. L. Barlow, J. H. C. Tosswill, J. V Parry, and J. P. Clewley, "Performance of the amplicor human immunodeficiency virus type 1 PCR and analysis of specimens with false-negative results," J. Clin. Microbiol., vol. 35, no. 11, pp. 2846-2853, 1997.

[65] J. W. Bremer, J. F. Lew, E. Cooper, G. V Hillyer, J. Pitt, E. Handelsman, D. Brambilla, J. Moye, and R. Haft, "Diagnosis of infection with human immunodeficiency virus type 1 by a DNA polymerase chain reaction assay among infants enrolled in the Women and Infants. Transmission study," J. Pediatr., vol. 129, pp. 198-207, 1996.

[66] C. Delamare, M. Burgard, and M. Mayaux, "HIV-1 RNA detection in plasma for the diagnosis of infection in neonates," J. Acquir. Immune Defic. Syndr. Hum. Retrovirol., vol. 15, no. 2, pp. 121-125, 1997.

[67] CDC, "HIV Testing Basics for Consumers," (2010). [Online]. Available: http://www.cdc.gov/hiv/topics/testing/resources/qa/index.htm

[68] C. Christopherson, Y. Kidane, B. Conway, H. Sheppard, S. Kwok, and J. Krowka, "PCR-based assay to quantify human immunodeficiency virus type 1 DNA in peripheral blood mononuclear cells these include : PCRbased assay to quantify human immunodeficiency virus type 1 DNA in peripheral blood mononuclear cells," J. Clin. Microbiol., vol. 38, pp. 630-634, 2000.

[69] N. Désiré, A. Dehée, V. Schneider, C. Jacomet, C. Goujon, P. Girard, W. Rozenbaum, and J. Nicolas, "Quantification of human immunodeficiency virus type 1 proviral load by a TaqMan real-time PCR assay," $J$. Clin. Microbiol., vol. 39, pp. 1303-1310, 2001.

[70] L. G. Kostrikis, G. Touloumi, R. Karanicolas, N. Pantazis, C. Anastassopoulou, J. J. Goedert, A. Hatzakis, and A. Karafoulidou, "Quantitation of human immunodeficiency virus type 1 DNA forms with the second template switch in peripheral blood cells predicts disease progression independently of plasma RNA load," J. Virol., vol. 76, pp. 10099-10108, 2002. 
[71] A. E. Hatzakis, G. Touloumi, N. Pantazis, C. G. Anastassopoulou, O. Katsarou, A. Karafoulidou, J. J. Goedert, and L. G. Kostrikis, "Cellular HIV-1 DNA load predicts HIV-RNA rebound and the outcome of highly active antiretroviral therapy," AIDS, vol. 18, pp. 2261-2267, 2004.

[72] D. Gibellini, M. Borderi, E. De Crignis, R. Cicola, L. Cimatti, F. Vitone, F. Chiodo, and M. C. Re, "HIV-1 DNA load analysis in peripheral blood lymphocytes and monocytes from naïve and HAART-treated individuals," J. Infect., vol. 56, no. 3, pp. 219-225, Mar. 2008.

[73] M. C. Re, F. Vitone, C. Biagetti, P. Schiavone, F. Alessandrini, I. Bon, E. de Crignis, and D. Gibellini, "HIV-1 DNA proviral load in treated and untreated HIV-1 seropositive patients," Clin. Microbiol. Infect., vol. 16, no. 6, pp. 640-646, Jun. 2010.

[74] S. M. Moroney, L. C. Heller, and R. H. Widen, "Evaluation of two TaqMan PCR assays for the detection of HIV-1 proviral DNA in blood samples," J. Microbiol. Methods, vol. 65, no. 2, pp. 350-353, May 2006.

[75] M. S. Malnati, G. Scarlatti, F. Gatto, F. Salvatori, G. Cassina, T. Rutigliano, R. Volpi, and P. Lusso, "A universal real-time PCR assay for the quantification of group-M HIV-1 proviral load," Nature Protocols, vol. 3, no. 7, pp. 1240-1248, Jul. 2008.

[76] A. De Rossi, M. Zanchetta, F. Vitone, G. Antonelli, P. Bagnarelli, L. Buonaguro, M. R. Capobianchi, M. Clementi, I. Abbate, F. Canducci, A. Monachetti, E. Riva, G. Rozera, C. Scagnolari, M. Tagliamonte, M. Carla, and I. Society, "Quantitative HIV-1 proviral DNA detection: A multicentre analysis," New Microbiol., vol. 33, pp. 293-302, 2010.

[77] S. R. Jangam, D. H. Yamada, S. M. McFall, and D. M. Kelso, "Rapid, point-of-care extraction of human immunodeficiency virus type 1 proviral DNA from whole blood for detection by real-time PCR," J. Clin. Microbiol., vol. 47, no. 8, pp. 2363-2368, Aug. 2009.

[78] S. R. Jangam, A. K. Agarwal, K. Sur, and D. M. Kelso, "A point-ofcare PCR test for HIV-1 detection in resource-limited settings," Biosens. Bioelectron., pp. 69-75, Oct. 2012.

[79] J.-H. Wang, L. Cheng, C.-H. Wang, W.-S. Ling, S.-W. Wang, and G.-B. Lee, "An integrated chip capable of performing sample pretreatment and nucleic acid amplification for HIV-1 detection," Biosens. Bioelectron., vol. 41, pp. 484-491, 2013.

[80] S. Y. Bae, H. C. Park, J. S. Oh, S.-Y. Yoon, D. W. Park, I. K. Choi, H. J. Kim, J. H. Oh, D. S. Hur, C. Chung, J. K. Chang, J. P. Robinson, and C. S. Lim, "Absolute CD4 cell count using a plastic microchip and a microscopic cell counter," Cytometry, vol. 76B, no. 5, pp. 345-353, Sep. 2009.

[81] W. R. Rodriguez, N. Christodoulides, P. N. Floriano, S. Graham, S. Mohanty, M. Dixon, M. Hsiang, T. Peter, S. Zavahir, I. Thior, D. Romanovicz, B. Bernard, A. P. Goodey, B. D. Walker, and J. T. McDevitt, "A microchip CD4 counting method for HIV monitoring in resource-poor settings," PLoS Med., vol. 2, no. 7, pp. 663-672, Jul. 2005.

[82] M. A. Alyassin, S. Moon, H. O. Keles, F. Manzur, R. L. Lin, E. Hæggstrom, D. R. Kuritzkes, and U. Demirci, "Rapid automated cell quantification on HIV microfluidic devices," Lab Chip, vol. 9, no. 23, pp. 3364-3369, Dec. 2009.

[83] S. Thorslund, R. Larsson, F. Nikolajeff, J. Bergquist, and J. Sanchez, "Bioactivated PDMS microchannel evaluated as sensor for human CD4+ cells-The concept of a point-of-care method for HIV monitoring," Sens. Actuators B, Chem., vol. 123, no. 2, pp. 847-855, May 2007.

[84] S. Thorslund, R. Larsson, J. Bergquist, F. Nikolajeff, and J. Sanchez, "A PDMS-based disposable microfluidic sensor for CD4+ lymphocyte counting," Biomed. Microdevices, vol. 10, no. 6, pp. 851-857, Dec. 2008.

[85] J. V Jokerst, P. N. Floriano, N. Christodoulides, G. W. Simmons, and J. T. McDevitt, "Integration of semiconductor quantum dots into nanobio-chip systems for enumeration of $\mathrm{CD} 4+\mathrm{T}$ cell counts at the pointof-need," Lab Chip, vol. 8, no. 12, pp. 2079-2090, Dec. 2008.

[86] J. V Jokerst, J. W. Jacobson, B. D. Bhagwandin, P. N. Floriano, N. Christodoulides, and J. T. McDevitt, "Programmable nano-bio-chip sensors: Analytical meets clinical," Anal. Chem., vol. 82, no. 5, pp. 15711579, Mar. 2010.

[87] X. Li, A. Ymeti, B. Lunter, C. Breukers, A. G. J. Tibbe, L. W. M. M. Terstappen, and J. Greve, "CD4+ T lymphocytes enumeration by an easy-to-use single platform image cytometer for HIV monitoring in resource-constrained settings," Cytometry, vol. 72B, no. 5, pp. 397-407, Sep. 2007.

[88] A. Ymeti, X. Li, B. Lunter, and C. Breukers, "A single platform image cytometer for resource-poor settings to monitor disease progression in HIV infection," Cytometry, vol. 71 A, no. 3, pp. 132-142, Mar. 2007.

[89] X. Li, A. G. J. Tibbe, E. Droog, L. W. M. M. Terstappen, and J. Greve, "An immunomagnetic single-platform image cytometer for cell enumer- ation based on antibody specificity," Clin. Vaccine Immunol., vol. 14, no. 4, pp. 412-419, Apr. 2007.

[90] X. Cheng, D. Irimia, M. Dixon, K. Sekine, U. Demirci, L. Zamir, R. G. Tompkins, W. Rodriguez, and M. Toner, "A microfluidic device for practical label-free CD4(+) T cell counting of HIV-infected subjects," Lab Chip, vol. 7, no. 2, pp. 170-178, Feb. 2007.

[91] X. Cheng, D. Irimia, M. Dixon, J. C. Ziperstein, U. Demirci, L. Zamir, R. G. Tompkins, M. Toner, and W. R. Rodriguez, "A microchip approach for practical label-free CD4+ T-cell counting of HIV-infected subjects in resource-poor settings," J. Acquir. Immune Defic. Syndr., vol. 45, no. 3, pp. 257-261, 2007.

[92] X. Cheng, A. Gupta, C. Chen, R. G. Tompkins, W. Rodriguez, and M. Toner, "Enhancing the performance of a point-of-care CD4+ T-cell counting microchip through monocyte depletion for HIV/AIDS diagnostics," Lab Chip, vol. 9, no. 10, pp. 1357-1364, May 2009.

[93] M. Beck, S. Brockhuis, N. van der Velde, C. Breukers, J. Greve, and L. W. M. M. Terstappen, "On-chip sample preparation by controlled release of antibodies for simple CD4 counting," Lab Chip, vol. 12, no. 1, pp. 167-173, Jan. 2012.

[94] C. D. Chin, V. Linder, and S. K. Sia, "Commercialization of microfluidic point-of-care diagnostic devices," Lab Chip, vol. 12, no. 12, pp. 2118 2134, Jun. 2012.

[95] S. Mtapuri-Zinyowera, M. Chideme, D. Mangwanya, O. Mugurungi, S. Gudukeya, K. Hatzold, A. Mangwiro, G. Bhattacharya, J. Lehe, and T. Peter, "Evaluation of the PIMA point-of-care CD4 analyzer in VCT clinics in Zimbabwe," J. Acquir. Immune Defic. Syndr., vol. 55, no. 1, pp. 1-7, Sep. 2010

[96] I. V Jani, N. E. Sitoe, P. L. Chongo, E. R. Alfai, J. I. Quevedo, O. Tobaiwa, J. D. Lehe, and T. F. Peter, "Accurate CD4 T-cell enumeration and antiretroviral drug toxicity monitoring in primary healthcare clinics using point-of-care testing," AIDS, vol. 25, no. 6, pp. 807-812, Mar. 2011.

[97] B. Larson, K. Schnippel, B. Ndibongo, L. Long, M. P. Fox, and S. Rosen, "How to estimate the cost of point-of-care CD4 testing in program settings: An example using the Alere Pima analyzer in South Africa," PLOS ONE, vol. 7, no. 4, pp. 1-8, Apr. 2012.

[98] Y. C. Manabe, Y. Wang, A. Elbireer, B. Auerbach, and B. Castelnuovo, "Evaluation of portable point-of-care CD4 counter with high sensitivity for detecting patients eligible for antiretroviral therapy," PLOS ONE, vol. 7, no. 4, pp. 1-5, Apr. 2012.

[99] S. Herbert, S. Edwards, G. Carrick, A. Copas, C. Sandford, M. Amphlett, and P. Benn, "Evaluation of PIMA point-of-care CD4 testing in a large UK HIV service," Sexually Transmitted Infect., vol. 88, no. 6, pp. 413417, Oct. 2012.

[100] I. Jani, N. Sitoe, J. Quevedo, J. Lehe, and T. Peter, "Cost comparison of point-of-care and laboratory CD4 testing in resource-limited settings,' presented at 6th IAS Conf. HIV Pathogenesis, Treatment Prevention, Rome, Italy, 2011.

[101] J. T. Gohring and X. Fan, "Label free detection of CD4+ and CD8+ $\mathrm{T}$ cells using the optofluidic ring resonator," Sensors, vol. 10 , no. 6 , pp. 5798-5808, Jun. 2010.

[102] S. Moon, H. O. Keles, A. Ozcan, A. Khademhosseini, E. Haeggstrom, D. Kuritzkes, and U. Demirci, "Integrating microfluidics and lensless imaging for point-of-care testing," Biosens. Bioelectron., vol. 24, no. 11, pp. 3208-3214, Jul. 2009.

[103] A. Ozcan and U. Demirci, "Ultra wide-field lens-free monitoring of cells on-chip," Lab Chip, vol. 8, no. 1, pp. 98-106, Jan. 2008.

[104] Z. Wang, S. Chin, C. Chin, and J. Sarik, "Microfluidic CD4+ Tcell counting device using chemiluminescence-based detection," Anal. Chem., vol. 82, no. 1, pp. 36-40, Jan. 2010.

[105] S. Moon, U. A. Gurkan, J. Blander, W. W. Fawzi, S. Aboud, F. Mugusi, D. R. Kuritzkes, and U. Demirci, "Enumeration of CD4+ T-cells using a portable microchip count platform in Tanzanian HIV-infected patients," PLOS ONE, vol. 6, no. 7, pp. 1-8, Jul. 2011.

[106] N. N. Mishra, S. Retterer, T. J. Zieziulewicz, M. Isaacson, D. Szarowski, D. E. Mousseau, D. A. Lawrence, and J. N. Turner, "On-chip microbiosensor for the detection of human CD4+ cells based on AC impedance and optical analysis," Biosens. Bioelectron., vol. 21, no. 5, pp. 696-704, Nov. 2005

[107] N. Mishra and S. Retterer, "Bio-impedance sensing device (BISD) for detection of human CD4+ cells," in Proc. NSTI Nanotechnol. Conf. Trade Show, 2004, pp. 228-231.

[108] X. Jiang and M. G. Spencer, "Electrochemical impedance biosensor with electrode pixels for precise counting of $\mathrm{CD} 4+$ cells: A microchip for 
quantitative diagnosis of HIV infection status of AIDS patients," Biosens. Bioelectron., vol. 25, no. 7, pp. 1622-1628, Mar. 2010.

[109] X. Cheng, Y. Liu, D. Irimia, U. Demirci, L. Yang, L. Zamir, W. R. Rodríguez, M. Toner, and R. Bashir, "Cell detection and counting through cell lysate impedance spectroscopy in microfluidic devices," Lab Chip, vol. 7, no. 6, pp. 746-755, Jun. 2007.

[110] P. Kiesel, M. Beck, and N. Johnson, "Monitoring CD4 in whole blood with an opto-fluidic detector based on spatially modulated fluorescence emission," Cytometry, vol. 79A, no. 4, pp. 317-324, Apr. 2011.

[111] J.-H. Wang, C.-H. Wang, C.-C. Lin, H.-Y. Lei, and G.-B. Lee, "An integrated microfluidic system for counting of CD4+/CD8 + T lymphocytes," in Microfluidics and Nanofluidics. vol. 10, New York, NY, USA: Springer, Mar. 2011, pp. 531-541.

[112] H. Yun, H. Bang, J. Min, C. Chung, J. K. Chang, and D.-C. Han, "Simultaneous counting of two subsets of leukocytes using fluorescent silica nanoparticles in a sheathless microchip flow cytometer," Lab Chip, vol. 10, no. 23, pp. 3243-3254, Dec. 2010.

[113] X. Mao, S.-C. S. Lin, C. Dong, and T. J. Huang, "Single-layer planar onchip flow cytometer using microfluidic drifting based three-dimensional (3D) hydrodynamic focusing," Lab Chip, vol. 9, no. 11, pp. 1583-1589, Jun. 2009.

[114] Y.-N. Wang, Y. Kang, D. Xu, C. H. Chon, L. Barnett, S. A. Kalams, D. $\mathrm{Li}$, and $\mathrm{D}$. Li, "On-chip counting the number and the percentage of CD4+ T lymphocytes," Lab Chip, vol. 8, no. 2, pp. 309-315, Feb. 2008.

[115] X. Wu, Y. Kang, Y.-N. Wang, D. Xu, D. Li, and D. Li, "Microfluidic differential resistive pulse sensors," Electrophoresis, vol. 29, no. 13, pp. 2754-2759, Jul. 2008.

[116] X. Wu, C. H. Chon, Y.-N. Wang, Y. Kang, and D. Li, "Simultaneous particle counting and detecting on a chip," Lab Chip, vol. 8, no. 11, pp. 1943-1949, Nov. 2008

[117] D. Holmes, D. Pettigrew, C. H. Reccius, J. D. Gwyer, C. van Berkel, J. Holloway, D. E. Davies, and H. Morgan, "Leukocyte analysis and differentiation using high speed microfluidic single cell impedance cytometry," Lab Chip, vol. 9, no. 20, pp. 2881-2889, Oct. 2009.

[118] C. van Berkel, J. D. Gwyer, S. Deane, N. G. Green, N. Green, J. Holloway, V. Hollis, and H. Morgan, "Integrated systems for rapid point of care (PoC) blood cell analysis," Lab Chip, vol. 11, no. 7, pp. 1249-1255, Apr. 2011.

[119] D. Holmes and H. Morgan, "Single cell impedance cytometry for identification and counting of CD4 T-cells in human blood using impedance labels," Anal. Chem., vol. 82, no. 4, pp. 1455-1461, Feb. 2010.

[120] N. Watkins, B. M. Venkatesan, M. Toner, W. Rodriguez, and R. Bashir, "A robust electrical microcytometer with 3-dimensional hydrofocusing," Lab Chip, vol. 9, no. 22, pp. 3177-3184, Nov. 2009.

[121] N. N. Watkins, S. Sridhar, X. Cheng, G. Chen, M. Toner, W. Rodriguez, and R. Bashir, "A microfabricated electrical differential counter for the selective enumeration of CD4+ T lymphocytes," Lab Chip, vol. 11, no. 8, pp. 1437-1447, Apr. 2011.

[122] H. Zhu, J. Yan, and A. Revzin, "Catch and release cell sorting: Electrochemical desorption of T-cells from antibody-modified microelectrodes," Colloids Surf. B Biointerfaces, vol. 64, no. 2, pp. 260-268, Jul. 2008.

[123] J. Robertus, W. R. Browne, and B. L. Feringa, "Dynamic control over cell adhesive properties using molecular-based surface engineering strategies," Chemical Soc. Rev., vol. 39, no. 1, pp. 354-378, Jan. 2010.

[124] U. A. Gurkan, T. Anand, H. Tas, D. Elkan, A. Akay, H. O. Keles, and U. Demirci, "Controlled viable release of selectively captured label-free cells in microchannels," Lab Chip, vol. 11, no. 23, pp. 3979-3989, Dec. 2011.

[125] C. Willyard, "Simpler tests for immune cells could transform AIDS care in Africa," Nature Med., vol. 13, no. 10, p. 1131, Oct. 2007.

[126] D. S. Boyle, K. R. Hawkins, M. S. Steele, M. Singhal, and X. Cheng, "Emerging technologies for point-of-care CD4 T-lymphocyte counting," Trends Biotechnol., vol. 30, no. 1, pp. 45-54, Jan. 2012.

[127] R. Zachariah, S. D. Reid, P. Chaillet, M. Massaquoi, E. J. Schouten, and A. D. Harries, "Viewpoint: Why do we need a point-of-care CD4 test for low-income countries?," Tropical Med. Int. Health : TM \& IH, vol. 16, no. 1, pp. 37-41, Jan. 2011.

[128] UNAIDS “UNAIDS World AIDS Day Report,” 2012.

[129] T. Quinn and M. Wawer, "Viral load and heterosexual transmission of human immunodeficiency virus type 1," New Engl. J. Med., vol. 342, no. 13, pp. 921-929, Mar. 2000. 